\title{
LATE QUATERNARY HISTORY OF SEDIMENTATION ON THE MAC. ROBERTSON SHELF, EAST ANTARCTICA: PROBLEMS WITH ${ }^{14} \mathrm{C}$-DATING OF MARINE SEDIMENT CORES
}

\author{
by P.T. Harris, P.E. O'Brien, P. Sedwick and E.M. Truswell
}

(with one table, one plate and four text-figures)

\begin{abstract}
Harris, P.T., O'Brien, P.E., Sedwick, P. \& Truswell, E.M., 1996 (xi): Late Quaternary History of sedimentation on the Mac. Robertson Shelf, East Antarctica: problems with ${ }^{14} \mathrm{C}$-dating of marine sediment cores. In Banks, M.R. \& Brown, M.J. (Eds): CLIMATIC SUCCESSIONS AND GLACIAL HIST ORY OF THE SOUTHERN HEMISPHERE OVER THE LAST FIVE MILLION YEARS. Pap. Proc. R. Soc. Tasm, 130(2): 47-53. https://doi.org/10.26749/rstpp.130.2.47 ISSN 0080-4703. Antarctic CRC,Australian Geological Survey Organisation, University of Tasmania, GPO Box 252-80, Hobart, Tasmania, Australia 7001 (PTH); Antarctic CRC, Australian Geological Survey Organisation, GPO Box 378, Canberra, ACT, Australia 2601 (PEO, EMT); and Antarctic CRC, University of Tasmania, GPO Box 252-80, Hobart, Tasmania, Australia 7001 (PS).
\end{abstract}

Stratigraphic information concerning the retreat of the Antarctic ice sheet from the continental shelf after the Last Glacial Maximum is reviewed and compared with new results from a shelf valley off Mac. Robertson Land, East Antarctica. Radiocarbon dates and detailed lithostratigraphic logs indicate that the onset of open-marine conditions over shallow shelf banks ( $<200 \mathrm{~m}$ water depth) was achieved prior to $7000 \mathrm{yr} \mathrm{BP}$ and over deep $(-1000 \mathrm{~m})$ middle to outer shelf valleys, open-marine conditions were achieved prior to $5400 \mathrm{yr}$ BP. Radiocarbon dating of bulk-organic carbon in some diatom oozes by the AMS method demonstrates problems of contamination. Jurassic pollen, spores and organic marter have been eroded and incorporated into Holocene diatom ooze, causing anomalously old ${ }^{14} \mathrm{C}$ dates (e.g. one surface age of $7084 \pm 86$ yr BP was determined). This problem may arise at other locations around East Antarctica where older strata outcrop on the seafloor.

Key Words: Antarctica, glacial retreat, continental shelf, radiocarbon dates, Holocene, Jurassic, sediment cores.

\section{INTRODUCTION}

The retreat of Northern and Southern Hemisphere ice sheets during the Late Pleistocene and early Holocene and the attendant eustatic sea-level rise are crucial factors in understanding and modelling global climate change during this time. Wheteas retreat of the Northern Hemisphere ice sheets was probably caused by Milankovich summer insolation, the Antarctic ice sheets responded to the resulting eustatic sea-level rise and global warming (e.g. Denton \& Hughes 1986, Budd \& Rayner 1993). Hence, one might expect the retreat of the Antarctic ice sheets to lag behind their Northern Hemisphere counterparts. However, only limited data have been published in the literature regarding the maximum extent and the timing of Antarctic ice-sheet retreat over this time period to eithet confirm or disprove this theory.

\section{Review of Previously Published Dates}

Radiocarbon dates for the ice-sheet retreat reported in the literature have been obtained from only five locations on the Antarctic continental shelf: the Mertz-Ninnis Trough, the Dumont d'Urville Trough, Prydz Bay, Anvers Island on the Antarctic Peninsula and the western Ross Sea (fig. 1).

Domack et al. (1991a) published details of 17 radiocarbon-dated marine sediment samples collected from three areas in East Antarctica: the Mertz-Ninnis Trough, the Dumont d'Urville Trough and Prydz Bay. These workers concluded that open-marine conditions, represented in cores by a diatom-rich, siliceous mud and ooze (SMO), were achieved after 10700 yr BP in Prydz Bay (fig. 1). The Prydz Bay site (ODP Site 740A) showed a facies succession interpreted by Domack et al. (1991a) as representing an episode of ice-proximal sedimentation from 7300 and 3800 yr BP that was attributed to increased glacial discharge during the Holocene hypsithermal event. This transition, into diatom-rich SMO from an underlying facies containing a higher terrigenous component, was dated at 5000 yr BP for the Mertz-Ninnis Trough and at $4300 \mathrm{yr}$ BP for the Dumont d'Urville Trough (Domack et al. 1991b). The overall thickness of Holocene beds in the Mertz-Ninnis and Dumont d'Urville Troughs is considered to be much greater than the cored interval, based on $3.5 \mathrm{kHz}$ echo sounder records (Domack et al. 1991b). Thus, these dates constrain the timing of the end of the mid-Holocene hypsithermal (and not the timing of glacial retreat from the shelf).

Pudsey et al. (1994) published details of nine radiocarbondated marine sediment samples collected from the Pacific margin of the Antarctic Peninsula, west of Anvers Island $\left(64^{\circ} 30^{\prime} \mathrm{S}, 65^{\circ} \mathrm{W}\right)$ in 536-575 $\mathrm{m}$ water depth. Reservoircorrected ages for the base of the open-marine sediment facies were about $11000 \mathrm{yr}$ BP. Seismic and sidescan sonar data were considered by Pudsey et al. (1994) to indicate that the ice-sheet was grounded at the shelf break during the last glacial maximum.

More recently, Domack et al. (1995a, b) reported on 56 AMS radiocarbon dates obtained from the western Ross Sea. Domack et al. (1995b) conclude that the outer Ross Sea shelf was not occupied by a grounded ice sheet during the last glacial maximum (at least as far back as $26000 \mathrm{yr}$ $\mathrm{BP})$, but rather that the ice was grounded on the mid-shelf in the vicinity of Coulman Island, consistent with the earlier studies of Taviani et al. (1993). Domack et al. (1995a) considered that the calving front of the floating ice tongue retreated past the Drygalski Trough by around 10000 to 8000 yr BP. 


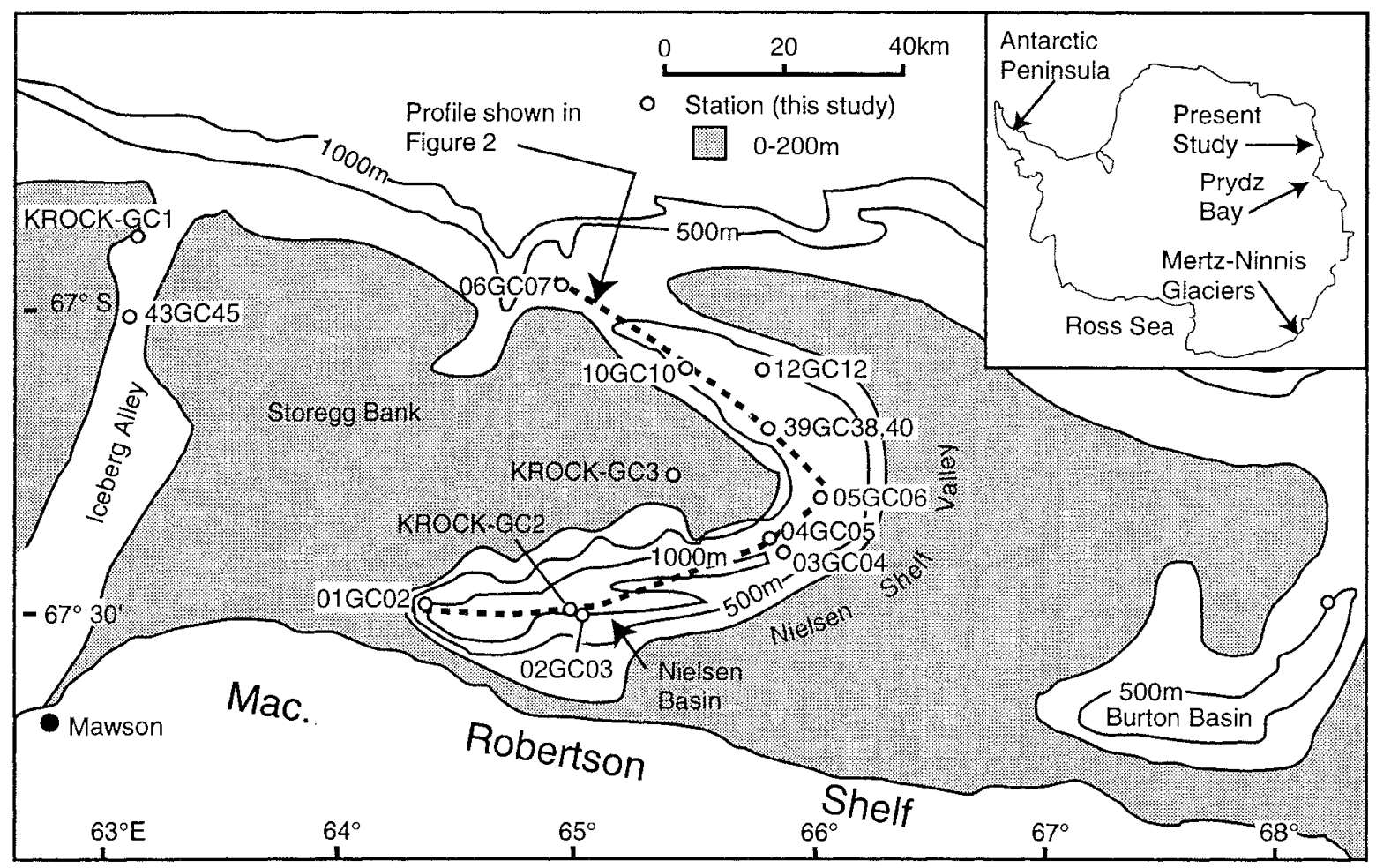

Fig. I-Location of the study area and other geographic areas discussed in the text. The location of the transect shown in figure 2 is indicated.

\section{Study Area - The Mac. Robertson Shelf}

The Mac. Robertson Shelf extends for about $400 \mathrm{~km}$ west from Prydz Bay and lies adjacent to Mac. Robertson Land, on the continental shelf of East Antarcrica (fig. 1). Shelf width is typically $90 \mathrm{~km}$ and the depth of the shelf break averages $350 \mathrm{~m}$. The shelf contains relatively shallow banks ( $<200 \mathrm{~m}$ deprh) that extend from the coastline onto the mid- to outer shelf. These banks are separated by basins which are more than $1200 \mathrm{~m}$ in depth locally and which are probably a common feature on the Antarctic shelf (cf. Johnson et al. 1982, Anderson \& Molnia 1989). The basins are sreep-sided (up to $70^{\circ}$, locally) and are joined to the shelf break by arcuate shelf valleys. These shelf valleys are fjordlike, being U-shaped in cross-section, and they were probably formed by glacial erosion during the Pleistocene (O'Brien et al. 1994, ten Brink \& Schneider 1995).

A marine geophysical expedition carried out in 1982 by the Australian Bureau of Mineral Resources (now the Australian Geological Survey Organisation [AGSO]) and the Australian National Antarctic Research Expeditions (ANARE) obrained $5000 \mathrm{~km}$ of six-fold seismic data in the Prydz Bay-Mac. Robertson Shelf area (Stagg et al. 1983, Stagg 1985). The inner part of the Mac. Robertson Shelf was found to be floored by shallow acoustic basement, considered to be Precambrian metamorphic and metasedimenrary rocks. On the outer shelf, Stagg (1985) described sedimentary sequence (PS2) at least $1000 \mathrm{~m}$ thick, containing complex sigmoid-oblique reflectors, prograding near the shelf edge with erosional truncation at the seabed and onlapping onto acousric basement.
O'Brien et al. (1994) described the general morphology of the Mac. Robertson Shelf based on a compilation of geophysical, sediment sample and bathymetric dara. These workers contrasted the thick, Quaternary glacial sediment packages found in Prydz Bay (particularly the Prydz Trough Mouth Fan) with the largely erosional surface forming the Mac. Robertson Shelf. The morphology of Storegg Bank (fig. 1) was noted to include 20-40 m steps, against which icebergs ground, similar to the ice erosion knick points described from the north slope of Alaska by Barnes et al. (1987). The sedimentary sequence PS2 described by Stagg (1985) was determined by O'Brien et al. (1994) to be Late Eocene in age, based on a sample containing spores, pollen and dinoflagellates dredged from Iceberg Alley (fig. 1).

Surficial shelf deposits have been described by Quilty (1985), based on 18 pipe-dredge samples. These samples included one from Nielsen Basin in $1250 \mathrm{~m}$ water depth and another from $415 \mathrm{~m}$ water depth, located about $10 \mathrm{~km}$ offshore from Mawson Base (fig. 1). These two stations comprised a "dominantly mud with diverse siliceous skeletal component" association. The other 16 samples were located on the upper continental slope and on low relief bank tops in depths of from 71 to $1166 \mathrm{~m}$ and comprised a "coarse sediment (biogenic and terrigenous)" association (Quilty 1985)

In this paper, data from gravity cores are presented, in an effort to provide a more detailed examination of Late Quaternary shelf deglaciation and the timing of the onset of present, open-marine environmental conditions on this part of the East Antarctic continental shelf. 


\section{METHODS}

Data available for the present study include the results of research cruises carried out during the Austral summers of 1992-93 and 1994-95 using RV Aurora Australis, operated by the Australian Antarctic Division. Bathymetric data were obrained using a Simrad EA200 $12.5 \mathrm{kHz}$ echo sounder. Seismic data were obtained using a Seismic Systems Inc. generator-injector (GI) gun in conjunction with an AGSOconstructed digital acquisition system and a $25 \mathrm{~m}$ Teledyne streamer with four groups (four channels) of ten hydrophones. Surficial sediment samples were obtained using Van Veen and Shipek grabs, and gravity cores were obtained using a 1-tonne bomb connected to 3 or $6 \mathrm{~m}$ lengths of $10 \mathrm{~cm}$ diameter core barrel $(9 \mathrm{~cm}$ diameter core liner).

In the laboratory, sediment core samples were wet-sieved to determine the percentage of gravel, sand and mud by dry weight. The sand and gravel fractions were examined by light microscopy, and visual estimates of the percentage of major constituents were made. The mud fraction in some samples was examined under a scanning electron microscope for major constituents. Calcium carbonate content was determined by the vacuum-gasometric technique, using a device constructed at the Antarctic CRC, according to the plan of Jones \& Kaiteris (1983). Biogenic silica (opal) was determined using the method outlined by Mortlock \& Froelich (1989). AMS ${ }^{1 / 4} \mathrm{C}$ dates were obtained on bulk organic carbon (with cold $\mathrm{HCl}$ wash to remove carbonates) and on carbonate samples by the Institute of Geological and Nuclear Sciences, Lower Hutt, New Zealand and the Australian Nuclear Science and Technology Organisation (ANSTO), Lucas Heights, New South Wales, Australia.

\section{RESULTS}

\section{Mac. Robertson Shelf Facies and Facies Successions}

The gravity cores document variations in sedimentary facies along the axis of the valley joining the Nielsen Basin to the shelf break (fig. 2). Holocene SMO forms a surface layer at least $3 \mathrm{~m}$ in thickness in the deepest parts of the basin $(3.5 \mathrm{kHz}$ data were not obtained at the core sites to estimate thicknesses of Holocene sediments), becoming thinner (0.5$1.5 \mathrm{~m}$ ) and more poorly sorted (greater sand and gravel content) with increasing distance seawards. Sediments on the outer shelf are slightly gravelly sands, and are probably reworked by grounded icebergs (ice-keel turbate) and strong currents, judging from sidescan sonographs and current meter data obtained in the area (Harris \& O'Brien, in press). Carbonate content on the outer shelf and shallow bank-top stations was between 5 and $35 \%$, but sediments in the deeper shelf valleys and basins contained no measurable calcium carbonate.

All of the cores along the shelf valley transect, apart from 06GC07 (fig. 2), contained an upper layer of SMO, composed of $10-60 \%$ angular, fine sand to coarse silt quartz and $20-50 \%$ biogenic silica. Sand content is around

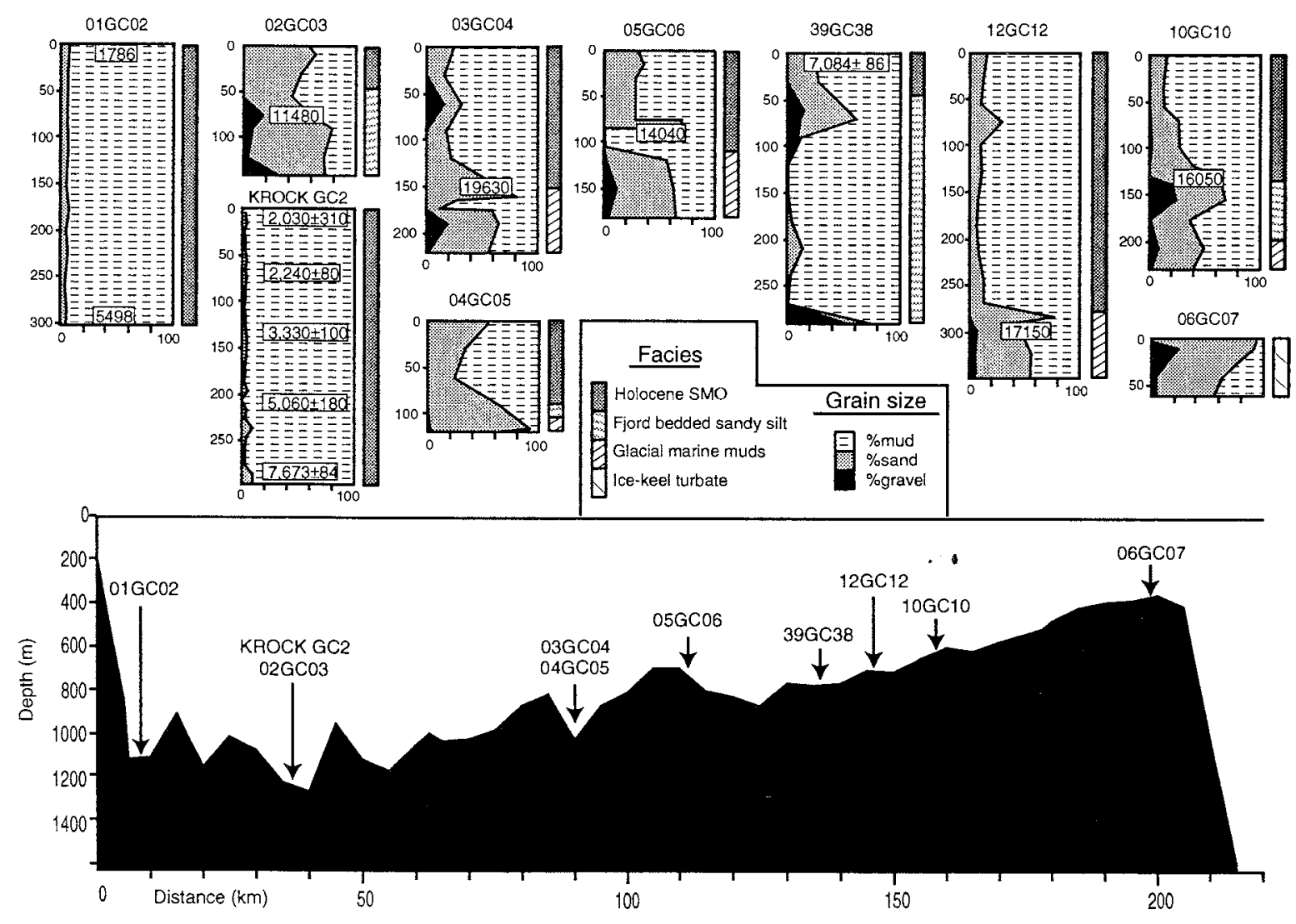

Fig. 2 - Vertical profile along the axis of the Nielsen Basin and core logs showing percentage of gravel, sand and mud, deduced facies and radiocarbon ages (see table 1 for details). 
$10 \%$ for inner shelf SMO deposits (e.g. 01GC02 and KROCK GC2), becoming greater seawards (fig. 2). The ice-keel turbate is 60-90\% sand, and generally it becomes more muddy down-core, suggestive of current winnowing (core 06GC07; fig. 2).

Visual inspection of the opal in the SMO suggests that it has been derived principally from the diatom Nitzschia curta, with trace amounts of radiolarians, forams and sponge spicules. Variations occur down-core in the abundance of opal (fig. 3); for example, at the base of core KROCK $\mathrm{GC2}$, biogenic silica content decreases from an average of about $40 \%$ to $25 \%$, with an attendant darkening in colour. In some cores, the abundance of opal decreases abruptly. This is interpreted as delimiting a facies boundary at the base of the SMO layer (e.g. cores 149/10GC10 and 149/ 12GC12; figs. 2, 3). The highest biogenic silica content $(56 \%)$ was measured in core $12 \mathrm{GC1} 2$ at $2 \mathrm{~m}$ subsurface and the opal abundance curve in this core also shows an apparent low $(32 \%)$ at $1.4 \mathrm{~m}$ with relatively higher values occurring above and below this level.

Underlying the SMO are two facies: (A) a bedded, medium to well-sorted, sandy-silt facies with beds $20 \mathrm{~mm}$ to $>0.2 \mathrm{~m}$ in thickness; and (B) a poorly sorted glacialmarine mud, with diatoms and calcareous fossils rare or absent. Sediments in both facies A and B comprised poor to medium sorted quartz, with minor amounts of garnet (probably derived from erosion of charnokitic basement), mica and lithic fragments. In some cases, these sediments were discovered to be rich in spores and pollen, as well as woody fragments and other plant debris. Although the lithological and mineralogical composition of the facies clearly indicates that they are of Late Pleistocene to Quaternary age, relatively "pure" assemblages of Jurassic to Early Cretaceous spores and pollen were recovered. This must indicate that the source rocks for the palynomorph assemblages are in the immediate vicinity. The integrity of the fossil suites and the lack of contamination by palynomorphs of different ages suggest that they have undergone little transport during the processes of glacial erosion. The spore and pollen suites range in age from Middle Jurassic at the seaward end of the Nielsen Shelf Valley, through to Late Jurassic and possibly Early Cretaceous at the shoreward end (Truswell et al., pers. obs.).

The particulate organic matter (POM or "maceral material"; see Hart 1986), which is so abundant in the sediments, is almost entirely made up of phytoclasts (pl. 1); spores and pollen, wood, rare cuticle fragments and even more rarely, walls of non-marine algae. The spore and pollen component (the exinite of coal petrography) in the Jurassic assemblages in sediments of the mid to outer Nielsen Shelf Valley consists largely of pollen of the family Araucariaceae. These phytoclasts show little biological degradation, although they are commonly fragmented. Pollen of extinct conifer groups is also present, as are spores of ferns and bryophytes. The woody component is largely made up of equidimensional opaque, probably carbonised fragments, but occasional tracheids retaining details of pit structures are present (pl. 1), and suggest that most of the wood is of coniferous origin. Cuticle fragments are rare and usually degraded. There are also aggregates of amorphous, granular humic matter, either the end product of degraded tissue or cell contents, but this material is not common. A few algal cells referable to Botryococcus have also been observed. The assemblages suggest freshwater deposics laid down through rapid burial, possibly in deltas

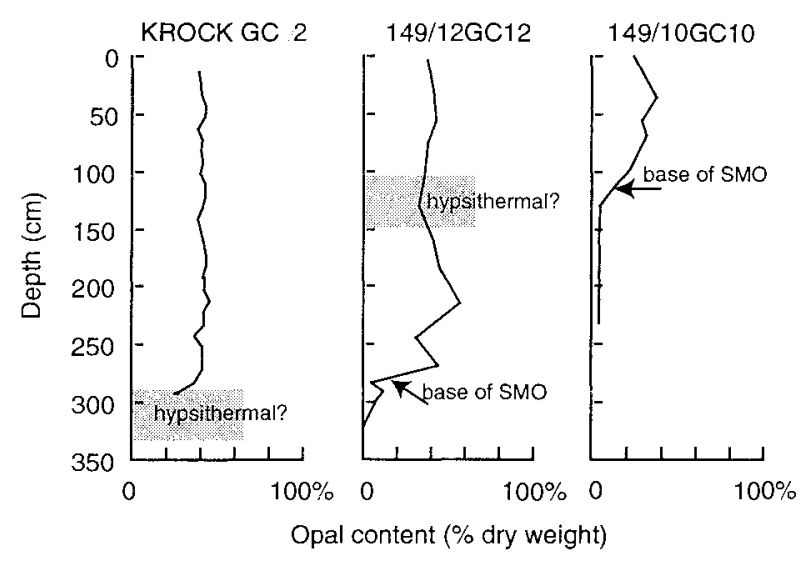

Fig. 3 - Abundance of opal (biogenic silica) for Nielsen Basin cores (see fig. 2 for grainsize data). Opal is reported as percent dry weight, assuming the formula: $\mathrm{SiO}_{2} \mathrm{O}_{4} 4 \mathrm{H}_{2} \mathrm{O}$ (Mortlock \& Froelich 1989).
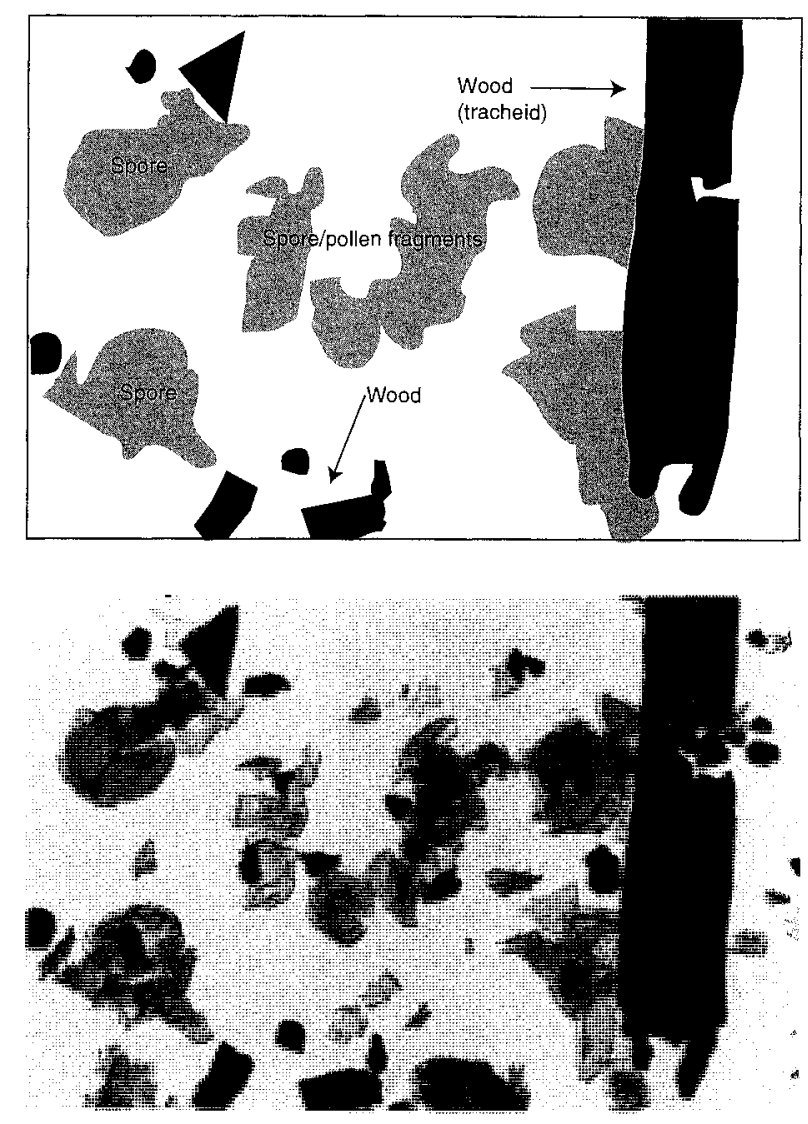

PLATE I

Photomicrograph and interpretive sketch (above) showing particulate organic matter from maceration of core cutter sample $04 G C 05$ (see frgs 1,2 for core location). The photograph shows araucarian pollen grains (roughly circular), pollen fragments, some diffuse humic matter and wood. Wood consists of angular or equidimensional fragments and a larger tracheid showing pit structures. 
associated with rift-valley fill, and incorporating plant debris from nearby coniferous forests.

We interpret facies $\mathrm{A}$ and $\mathrm{B}$ as being deposited under floating ice in a low-energy, fjord environment. Because facies $B$ is more poorly sorted, we interpret it as being more proximal to the grounding line moraine, with facies $A$ being more distal. At other locations around East Antarctica, the succession of facies ( $\mathrm{B}$ to $\mathrm{A}$ to SMO) has been interpreted to represent ice-sheet retreat and onset of open marine conditions on the shelf (Domack et al. 1991a). Based on this hypothesis, radiocarbon dating of core samples from the base of the SMO was attempted to provide information on the timing of the ice-sheet retreat and onset of modern, open marine shelf conditions.

\section{Mac. Robertson Shelf ${ }^{14} \mathrm{C}$ Dates}

Our radiocarbon dates are listed in table 1, and spatial relationships are shown in figure 2 . The material dated ranges in age from $1786 \pm 71 \mathrm{yr}$ BP for a core-top sample from the Nielsen Basin up to a maximum age of $19630 \pm 180$ yr BP for a sample taken at the SMO-glacialmarine mud facies boundary. One sample taken from this facies boundary (fig. 2) is early Holocene $7673 \pm 84$ yr BP (KROCK GC2) and another from deep in the SMO layer gave an age of $5498 \pm 88$ yr BP (01GC02). The other samples obtained from this facies boundary are of a variety of ages between $19630 \pm 180$ and $11480 \pm 130 \mathrm{yr} \mathrm{BP}$.

\section{DISCUSSION}

Jurassic organic matter is clearly visible in some cores, generally restricted to the glacial-marine, sub-ice sheet facies $\mathrm{A}$ and $\mathrm{B}$. However, the ${ }^{14} \mathrm{C}$ dates obtained from what is considered to be the base of the Holocene show an unusually wide variability (table 1 ). We attribute this variability to contamination of Holocene carbon with recycled Jurassic material. Because of this contamination, ages appear to be much older than the anticipated Holocene ages. For example, the surface date of 7084 yr BP for core $39 \mathrm{GC} 38$ supports this explanation (table 1).

On the other hand, we consider that the cores from the landward end of the Nielsen Basin (i.e. cores 01GC02 and KROCK GC2) are not contaminated, and that the radiocarbon ages are a reliable indication of the sediment age. Evidence in support of this is that the Jurassic pollen and dark, woody material were not found in the SMO beds of these cores, and the ages of the near-surface sediments (1786 and 2030 yr BP) appear consistent and explainable in the context of a reservoir correction. The apparent reason for the non-contamination of these inner shelf cores is that the basement outcropping on the sides of the Nielsen Basin, where the core are located (fig. 1), comprises crystalline metasedimentary rock (charnockite), that is devoid of organic matter. Seismic data show that younger Mesozoic sediments crop out only on the mid to outer shelf (Harris \& O'Brien, in press). The disposition of the Mesozoic sediments and their restriction to the mid to

TABLE 1

AMS radiocarbon ages determined

\begin{tabular}{|c|c|c|c|c|c|}
\hline $\begin{array}{l}\text { Core } \\
\text { Number }\end{array}$ & $\begin{array}{l}\text { Core depth } \\
\text { (cm) }\end{array}$ & $\begin{array}{l}\text { Water depth } \\
\text { (m) }\end{array}$ & $\begin{array}{c}\delta^{13} \mathrm{C} \% 0^{*} \\
\mathrm{PDB}\end{array}$ & $\begin{array}{l}\text { Age }^{\dagger} \\
(\text { yr BP) }\end{array}$ & $\begin{array}{l}\text { Lab ref. } \\
\text { number }\end{array}$ \\
\hline $149 / 01 G C 02$ & $0-1$ & 1100 & -24.5 & $1786 \pm 71$ & NZA5779 \\
\hline $149 / 01 \mathrm{GC0} 2$ & $302-303$ & 1100 & -24.4 & $5498 \pm 88$ & NZA 5782 \\
\hline $149 / 02 \mathrm{GC0} 3$ & $87-88$ & 1200 & -25.6 & $11480 \pm 130^{5}$ & NZA5784 \\
\hline 149/03GC04 & $165-166$ & 855 & -23.5 & $19630 \pm 180^{\$}$ & NZA5785 \\
\hline $149 / 05 \mathrm{GCO} 6$ & $85-86$ & 805 & -26.1 & $14040 \pm 170^{5}$ & NZA5783 \\
\hline $149 / 10 \mathrm{GC} 10$ & $135-136$ & 627 & -26.9 & $16050 \pm 160^{\$}$ & NZA 5787 \\
\hline $149 / 12 \mathrm{GC} 12$ & $301-302$ & 626 & -26.3 & $17150 \pm 280^{5}$ & NZA5763 \\
\hline $149 / 39 \mathrm{GC} 38$ & $0-1$ & 620 & -27.8 & $7084 \pm 86^{\$}$ & NZA5905 \\
\hline $149 / 39 \mathrm{GC} 40$ & $67-68$ & 620 & -28.9 & $17870 \pm 150^{\$}$ & NZA5906 \\
\hline $149 / 43 \mathrm{GC} 45$ & $168-169$ & 354 & -28.0 & $15960 \pm 200$ & NZA5907 \\
\hline KROCK GCl & $356-357$ & 478 & -23.67 & $12250 \pm 110$ & NZA4639 \\
\hline KROCK GC2 & $7-8$ & 1091 & -24.25 & $2030 \pm 310$ & OZB098 \\
\hline KROCK GC2 & $78-80$ & 1091 & -24.25 & $2420 \pm 80$ & OZB099 \\
\hline KROCK GC2 & $147-148$ & 1091 & -24.25 & $3330 \pm 100$ & OZB100 \\
\hline KROCK GC2 & $218-219$ & 1091 & -24.25 & $5060 \pm 180$ & OZB101 \\
\hline KROCK GC2 & $281-283$ & 1091 & -24.25 & $7673 \pm 84$ & NZA4640 \\
\hline KROCK GC3 & $14-15$ & 134 & 0.69 & $4314 \pm 96$ & NZA4813 \\
\hline KROCK GC3 & $55-57$ & 134 & 0.68 & $8030 \pm 110$ & NZA4814 \\
\hline
\end{tabular}

* The values of $\delta^{13} \mathrm{C} \% 0$ correspond to different sources of organic matter (bulk organic matter in the range -24 to -29 , versus calcite in the range 0.68 to 0.69 ).

$\dagger$ The ages given are uncorrected, conventional radiocarbon years BP (yr BP).

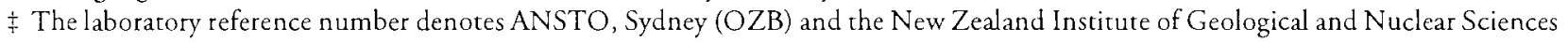
Rafter Radiocarbon Laboratory, Lower Hutc (NZA).

$\$$ The core samples with a (J) contained Jurassic amber, wood and other organic matter (pl. 1) and are considered to have yielded erroneous ${ }^{14} \mathrm{C}$ dates due to contamination. 
outer shelf explain why it is only the outer-shelf cores that contain organic matter from this source. Glacial advance down the axis of the shelf valley and attendant bulldozing of sediment seawards to the outer shelf would also explain the absence of any of this material in the deep, inner-shelf basins.

A plot of the down-core ${ }^{14} \mathrm{C}$ dates for KROCK GC2 (fig. 4) demonstrates a consistent trend that also lends support to our interpretation of this core as not being affected by contamination. Linear regression analysis shows a good age-depth correlation $(\mathrm{R}=0.96)$, and extrapolation of the line indicates a surface age of $1057 \mathrm{yr} \mathrm{BP}$ (which is realistic for the present Antarctic ocean reservoir age); subtracting this correction yields a basal age of 5447 yr BP. This is a minimum age estimate of onset of SMO deposition, because core KROCK GC2 bottomed in SMO and the overall thickness of SMO at the site is unknown.

The carbonate material dated in core KROCK GC3 is also unaffected by contamination because these ages are based on hand-picked tests of fresh foraminifers. This core did not penetrate through the Holocene facies into any underlying, glacial (or sub-ice shelf) facies. Hence the age of $8030 \mathrm{yr}$ BP less a reservoir correction (-1000 yr?) provides a minimum estimate of the exposure of the mid-shelf banks (in $-130 \mathrm{~m}$ water depth) to open-marine conditions (i.e. about 7000 yr BP).

Ages from the inner shelf SMO cores indicate that the inner-shelf basins achieved fully open marine conditions prior to about 5400 yr BP This coincides with slightly higher sand content (fig. 2) and decreased biogenic silica content measured towards the base of core KROCK GC2 (fig. 3). Our interpretation of this core is that its lowest part represents the last phase of the mid-Holocene hypsithermal as proposed by Domack et al. (1991a). Further, the slight depression in the biogenic silica curve for core 12 GC12 (fig. 2) may also represent the effect of the hypsithermal, which is explained by a relative increase in glacial discharge of terrigenous sediment supply, as a consequence of slightly warmer climatic conditions than at present. The $0.25 \mathrm{~m}$ thick SMO facies from core $12 \mathrm{GC} 12$ did not appear to contain Jurassic organic matter, and radiocarbon dating of this facies should permit an estimate of sedimentation rate and a chronology for the opal\% data.

\section{SUMMARY AND CONCLUSIONS}

Sedimentological analyses and radiocarbon dating of a series of cores obtained along the axis of the Nielsen Shelf Valley indicate that fully open marine conditions on the Mac. Robertson Shelfwere achieved prior to $7000 \mathrm{yr}$ BP. A decrease in biogenic silica below this depth in one core (KROCK GC2) is interpreted as a product of increased terrigenous sediment influx associated with the mid-Holocene hypsithermal event (Domack et al. 1991a). Mid-shelf banks experienced open-marine conditions as long ago as at least $8000 \mathrm{yr} \mathrm{BP}$, following ice-sheet retreat from the continental shelf. None of our bulk organic carbon dates, obtained from the base of assumed Holocene units, provide a reliable absolute age estimate of the timing of glacial retreat because of contamination problems.

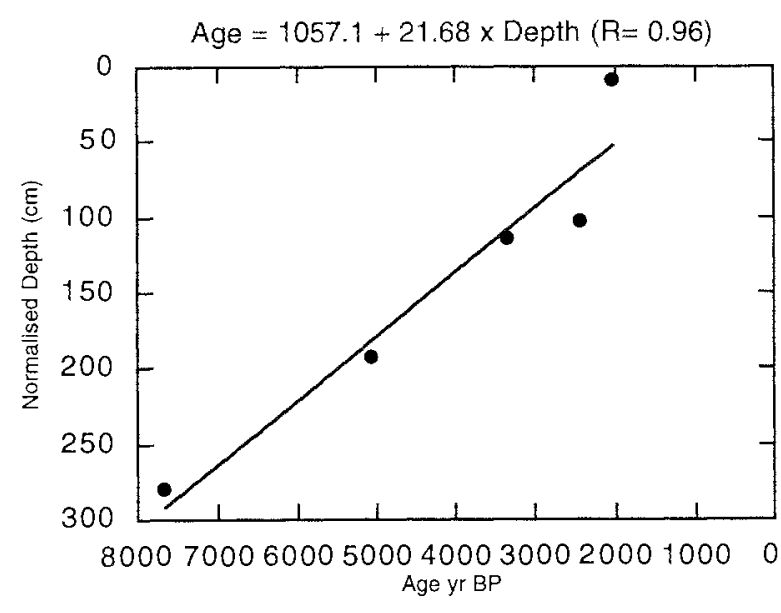

Fig. 4 - Plot of ${ }^{14} C$ ages versus depth for core KROCK GC2. Depths have been normalised with respect to water content to correct for sediment compaction.

The lesson from the Mac. Robertson Shelf, that ancient strata may provide a source of organic matter that can cause contamination of Holocene biosiliceous material and affect bulk organic carbon dates, may be applicable to other locations on the Antarctic margin. While the sediments in the outer Nielsen Shelf Valley are particularly rich in ancient particulate organic matter, recycled phytoclasts have been shown to be common in Quaternary muds at many localities on the Antarctic continental shelf. Spores and pollen of Tertiary and Cretaceous age have been reported from widely separated sites on the East Antarctic margin (Truswell 1982) and, in the Ross Sea, they are sufficiently abundant to be used in a quantitative fashion as markers to define the sedimentary inputs from separate ice streams within the Ross Ice Shelf (Truswell \& Drewry 1984). Cretaceous strata are known to crop out on the shelf near George Vth Land (Domack et al. 1980). Thus, interpretation of bulk organic carbon dates from presumed Holocene Antarctic shelf deposits must be undertaken with caution. Use of numerous dates to establish an accumulation rate within an homogenous sedimentary unit may provide an alternative to absolute dating in some cases.

\section{ACKNOWLEDGEMENTS}

The work described in this paper was financially supported by the Cooperative Research Centre for the Antarctic and Southern Ocean Environment, University of Tasmania and by the Australian Geological Survey Organisation. Thanks to the captain and crew of the RV Aurora Australis and to the personnel who assisted with the data collection; D. Sewter, S. Milne, H. Miller, W. Wierzbicki, R. Weldon, C. Boucher, D. Moser, P. Brodie, T. Ryan, P. Wells and F. Taylor. Thanks also to L. Robertson, R. Connell, C. Findlay for assistance in the laboratory. The authors publish with the permission of the Executive Director, Australian Geological Survey Organisation. 


\section{REFERENCES}

ANDERson, J.B. \& Molnia, B.F., 1989: GLACIAL-MARINE SEDIMENTATION. In SHORT COURSE IN GEOLOGY, Vol. 9. American Geophysical Union, Washington DC: $127 \mathrm{pp}$.

Barnes, P.W., Ashbury, J.L., Rearic, D.M., \& Ross, C.R, 1987: Ice erosion of a seafloor knickpoint at the inner edge of the Stamukhi Zone, Beaufort Sea, Alaska. Mar. Geol. 76: 207-222.

BudD, W. F. \& RAYNER, P., 1993: Modelling ice sheet and climatic changes through the ice ages. In Peltier, W.R. (Ed.): ICE IN THE CLIMATE SYSTEM. SpringerVerlag, Heidelberg: 29I-319.

Denton, G.H. \& Hughes, T.J, 1986: Global ice-sheet system interlocked by sea level. Quat. Res. 26: 3-26.

DOMack, E.W., FaIrChild, W.W. \& ANDERSON, J.B., 1980 Lower Cretaceous sediment from the East Antarctic continental shelf. Nature 287: 625-626.

DOMACK, E.W., Jull, A.J.T. \& NAKAO, S., I99la: Advance of East Antarctic outlet glaciers during the Hypsithermal: implications for the volume state of the Antarctic ice sheet under global warming. Geology 19: 1059-1062.

Domack, E.W., Jull, A.J.T., Anderson, J.B. \& Linick, T.W., 1991b: Mid-Holocene ice sheet recession from Wilkes Land continental shelf, East Antarctica. In Thomson, M.R.A., Crame, J.R. \& Thomson, J.W. (Eds): GEOLOGICAL EVOLUTION OF ANTARCTICA. Cambridge University Press: 693-698.

Domack, E.W., Hilfinger, M., \& Franceschinl, J., 1995a: Stratigraphic and facies relationships in the Ross Sea related to Late Pleistocene fluctuation of the west Antarctic ice sheet system. In Third Annual West Antarctic Ice Sheet Initiative Science Workshop, Washington DC.

Domack, E.W., Hilfinger, M., Franceschini, J., Licht, K., Jennings, A., Andrews, J.T., Shipp, S. \& Anderson, J.B., 1995b: New stratigraphic evidence from the Ross Sea continental shelf for instability if the West Antarctic ice sheet during the late Pleistocene. In First Congress on Sedimentary Geology, St. Pete Beach, Florida. SEPM, Tulsa, Oklahoma.

Harris, P.T., \& O'Brien, P.E., in press: Geomorphology of the continental shelf adjacent to Mac. Robertson Land, East Antarctica: a scalped shelf. Geo-Mar. Lett.

HART, G.F. 1986. Origin and classification of organic matter in clastic systems. Palynology 10: 1-23.
Johnson, G.L., Vanney, J.R. \& Hayes, D., 1982: The Antarctic continental shelf. In Craddock, C. (Ed.): ANTARCTIC GEOSCIENCE. University of Wisconsin Press, Madison: 995-1002

JONES, G. A. \& KATterIS, P., 1983: A vacuum-gasometric technique for rapid and precise analysis of calcium carbonate in sediments and soils. J. Sediment. Petrol. 53: 655-660.

Mortlock, R.A. \& Froelich, P.N., 1989: A simple method for the rapid determination of biogenic opal in pelagic marine sediments. Deep-Sea Res. 36(9): 1415-1426.

O'Brien, P.E., Truswell, E.M. \& Burton, H., 1994: Morphology, seismic stratigraphy and sedimentation history of the Mac. Robertson shelf, East Antarctica. Terra Antarct. 1(2): 407-408.

Pudsey, C.J., Barker, P.F. \& Larter, R.D., 1994: Ice sheet retreat from the Antarctic Peninsula shelf. Cont. Shelf Res. 14: 1647-1675.

Quilty, P., 1985: Distribution of foraminiferids in sediments of Prydz Bay. S. Aust. Dep. Mines Energy Spec. Publ. 5: 329340.

StagG, H.M.J., 1985: The structure and origin of Prydz Bay and Mac Robertson shelf, East Antarctica. Tectonophysics 114: 315-340.

StagG, H.M.J., Ramsay, D.C. \& Whitworth, R., 1983: A preliminary report of a marine geophysical survey between Davis and Mawson Stations, 1982. In Oliver, R.L., James, P.R. \& Jago, J.B. (Eds): PROCEEDINGS OF THE FOURTH INTERNATIONAL SYMPOSIUM ON ANTARCTIC EARTH SCIENCE, CANBERRA. Australian Academy of Science: 527-532

Taviani, M., Reid, D.E. \& Anderson, J.B., 1993: Skeletal and isotopic composition and paleoclimatic significance of Late Pleistocene carbonates, Ross Sea, Antarctica. J. Sediment. Petrol. 63: 84-90.

TEN BRinK, U.S. \& SCHNeider, C., 1995: Glacial morphology and depositional sequences of the Antarctic continental shelf. Geology 23(7): 580-584.

TRUSWELL, E.M., 1982: Palynology of sea-floor samples collected by the 1911-1914 Australasian Antarctic Expedition; implications for the geology of coastal East Antarctica. J. Geol. Soc. Aust. 29: 343-56.

Truswell, E.M. \& Drewry, D.J., 1984: Distribution and provenance of recycled sediments in surficial sediments of the Ross Sea, Antarctica. Mar. Geol. 59: 187-214.

(accepted 13 August 1996) 